\title{
Modified Pumpkin Flour Using Hydrogen Rich Water with a Microwave Dryer
}

\section{Modifikasi Tepung Labu Kuning Menggunakan Hydrogen Rich Water dengan Pengering Gelombang Mikro}

\author{
Gita Indah Budiarti ${ }^{a, 1, *}$, Ayu Wulandari ${ }^{a, 2}$, Siti Mutmaina ${ }^{a, 3}$, Endah Sulistiawati ${ }^{a, 4}$ \\ a Program Studi Teknik Kimia, Universitas Ahmad Dahlan Yogyakarta, Indonesia \\ ${ }^{1}$ gita.indah@che.uad.ac.idr*; ${ }^{2}$ ayu1700020020@webmail.uad.ac.id; ${ }^{3}$ siti1700020026@webmail.uad.ac.id; ${ }^{4}$ endahsulistiawati@che.uad.ac.id \\ * corresponding author
}

\section{ARTICLE INFO}

Article history

Received April 01, 2020

Revised April 28, 2020

Accepted June 09, 2020

\section{Keywords}

Labu Kuning

Gelombang mikro

Hydrogen Rich Water

Modifikasi tepung

\section{ABSTRACT}

Pumpkin is a fruit that contains fiber and vitamin A which works to prevent diabetes. Pumpkin's use is not optimal, so it needs innovation for Pumpkin, one of which is to make Pumpkin into flour. Pumpkin does not have gluten, so modification is needed. Modifications used are using hydrogen-rich water with a microwave dryer. Hydrogen-rich water has antioxidant content and is safer for the modification of starch food. The purpose of this study was to determine the physicochemical properties (water content and expandability) and beta carotene levels in HRWmodified flour using a microwave dryer. First, Pumpkin soaked with a variation of time 1, 2, 3, 4, and 5 hours. The optimal results of water capacity and beta carotene levels were obtained at the immersion time of 1 hour by $11 \%, 7.4 \mathrm{~g} / \mathrm{g}$ of sample, and 3,164.79 $\mu \mathrm{g} / \mathrm{g}$. The results obtained are higher than the modification of $H R W$ without a microwave dryer.

This is an open access article under the CC-BY-SA license.

\section{Pendahuluan}

Labu kuning merupakan tanaman lokal yang melimpah di Indonesia. Labu kuning dapat menurunkan resiko penyakit kanker karena buahnya memiliki pigmen yang dikenal sebagai beta karoten. Beta karoten merupakan penyebab buah labu kuning berwarna oranye kekuningan. Labu kuning dapat menjaga kesehatan jantung serta mengendalikan diabetes karena mengandung serat, vitamin A (beta karoten), dan kalium [1]. Kandungan beta karoten pada buah labu kuning sebesar $2100 \mu \mathrm{g} / 100 \mathrm{~g}$ [2]. Pemanfaatan labu kuning selama ini hanya dimakan secara langsung atau dibuat menjadi sup [3].

Dengan berkembangnya inovasi dalam dunia pangan, konsumen lebih menginginkan penyajian produk pangan yang praktis, sehingga labu kuning berpotensi untuk diolah menjadi tepung agar lebih praktis dan memperpanjang umur simpannya. Labu kuning memiliki daya simpan yang cukup lama namun volumenya besar dan mudah rusak dalam pengangkutan, sehingga perlu diolah menjadi suatu produk yang lebih tahan lama disimpan dan praktis, seperti tepung [4]. Inovasi labu kuning menjadi tepung ini dapat meningkatkan pendapatan petani.

Tepung labu kuning ini selanjutnya digunakan untuk membuat produk makanan seperti roti, cake dan biskuit dengan cara mensubtitusikannya dengan tepung terigu. Tepung labu kuning memiliki kandungan selulosa sebanyak 40\%, 4,3\% hemiselulosa, dan 4,3\% lignin [1]. Menurut Juanda [5], selama ini tepung labu kuning dapat menggantikan tepung terigu $10 \%$ saja dari berat tepung keseluruhan. Hal ini dikarenakan tepung labu kuning tidak mengandung gluten seperti tepung terigu. 
Teknik modifikasi dapat digunakan untuk menanggulangi kelemahan-kelemahan dari pati dan menghasilkan pati dengan sifat-sifat yang lebih baik dan spesifik. Pati demikian ini disebut sebagai "pati termodifikasi (modified starch)". Dalam arti luas, setiap produk dimana sifat kimia dan atau sifat fisik pati biasa telah diubah disebut sebagai pati termodifikasi. Pati termodifikasi menurut Zulaidah [6] adalah pati yang gugus hidroksilnya telah diubah lewat suatu reaksi kimia (esterifikasi, sterifikasi atau oksidasi) atau dengan menggangu struktur asalnya. Perlakuan ini dapat mencakup penggunaan panas, asam, alkali, zat pengoksidasi atau bahan kimia lainnya yang akan menghasilkan gugus kimia baru dan/atau perubahan bentuk, ukuran serta struktur molekul pati.

Modifikasi tepung antara lain menggunakan asam, enzim dan cara fisika yaitu dengan pemanasan [7]. Kelemahan dari modifikasi asam adalah kurang aman bagi makanan apabila proses pemurniannya tidak baik. Modifikasi dengan enzim relatif lebih aman bagi makanan, namun harga enzim yang mahal dan perlakuan mikroba penghasil enzim yang sulit, mengakibatkan harga produk yang tinggi. Modifikasi pemanasan dapat menyebabkan kandungan vitamin A pada labu kuning akan rusak [7], sehingga perlu dilakukan metode lain untuk memodifikasi tepung labu kuning. Hydrogen Rich Water (HRW) adalah air hasil elektrolisis yang memiliki kandungan hidrogen lebih banyak daripada air biasa [8]. HRW memiliki kandungan antioksidan, sehingga lebih menyehatkan. Selain itu, penggunaan HRW lebih aman untuk makanan [8].

Penelitian serupa pernah dilakukan oleh Budiarti dan Sulistiawati [9], bedanya, pada penelitian ini menggunakan pengering gelombang mikro, sedangkan penelitian sebelumnya menggunakan oven dan sinar matahari. Gelombang mikro merupakan alat pengering yang efektif karena dapat memanaskan reaktan dengan lebih selektif, langsung dan tanpa adanya pertukaran panas dengan medium [10]. Modifikasi dengan HRW menggunakan bantuan gelombang mikro sudah pernah dilakukan dengan bahan kentang, hasil fisikokimia yang dihasilkan lebih tinggi dibandingkan terigu [11]. Penelitian ini bertujuan untuk mengetahui sifat fisikokimia yaitu kadar air dan swelling power serta kandungan beta karoten pada tepung labu kuning.

\section{Metode Penelitian}

\subsection{Alat dan Bahan}

Alat yang digunakan pada penelitian ini adalah pengering gelombang mikro merk SHARP, centrifuge, blender, ayakan 80 mesh. Bahan yang digunakan pada penelitian ini adalah buah labu kuning dari Pasar Giwangan Yogyakarta. Hydrogen Rich Water dengan $\mathrm{pH} 9$ dihasilkan dari bahan baku air mineral menggunakan mesin elektrolisis Leveluk SD-501.

\subsection{Tahap Persiapan Bahan}

Labu kuning dikupas dan dicuci terlebih dahulu, kemudian dibuat chips setebal kira-kira $2 \mathrm{~mm}$.

\subsection{Tahap Perlakuan}

Potongan labu kuning direndam hidrogen rich water dengan $\mathrm{pH} 9$ sebanyak $300 \mathrm{~mL}$ dengan variasi waktu 1, 2, 3, 4, dan 5 jam. Kemudian sampel tersebut dikeringkan menggunakan pengering gelombang mikro. Setelah dikeringkan sampel tersebut diblender dan diayak dengan ayakan 80 mesh.

\subsection{Tahap Analisis}

Analisis yang dilakukan adalah analisis sifat fisikokimia meliputi:

\subsubsection{Kadar air}

Kadar air menggunakan metode thermogravimetri menurut SNI 3751:2009 [12]. Botol timbang dipanaskan ke dalam oven pada suhu $130-133{ }^{\circ} \mathrm{C}$ selama 1 jam. Sampel sebanyak 2 gram $\left(\mathrm{W}_{1}\right)$ ditimbang kemudian dimasukkan dalam botol timbang dikeringkan menggunakan oven selama 1 jam, pada suhu $130-133{ }^{\circ} \mathrm{C}$. Metode penimbangan dan pengovenan dilakukan sampai berat sampel konstan $\left(\mathrm{W}_{2}\right)$. Kadar air dihitung menggunakan rumus :

Kadar air $=\frac{W_{1}-W_{2}}{W_{1}} \times 100 \%$ 


\subsubsection{Daya kembang (swelling power)}

Daya kembang tepung (swelling power) tepung labu kuning dihitung menggunakan metode Leach [13]. Sampel sebanyak 0,1 gram dilarutkan dalam $10 \mathrm{~mL}$ aquades. Larutan sampel dipanaskan dalam water bath selama 30 menit pada suhu $60^{\circ} \mathrm{C}$. Kemudian dimasukan ke dalam centrifuge selama 30 menit dengan kecepatan $2500 \mathrm{rpm}$ untuk memisahkan antara filtrat dan endapan. Selanjutnya endapan ditimbang. Swelling power dapat dihitung menggunakan rumus berikut :

swelling power $(\mathrm{g} / \mathrm{g})=\frac{\text { berat pasta }(\mathrm{g})}{\text { berat sampel kering }(\mathrm{g})}$

\subsubsection{Analisis beta karoten}

Analisis beta karoten dilakukan menggunakan metode Gross [14]. Sampel dihaluskan dan ditambah $\mathrm{CaCO}_{3}$. Kemudian sampel diekstrak menggunakan pelarut petroleum eter (PE) dan etanol. Residu dari ekstrak tersebut diekstrak kembali menggunakan pelarut baru. Hasil ekstraksi dipekatkan dengan rotary evaporator dan dikeringkan dengan oven. Setelah ekstrak sampel kering dianalisis menggunakan Spektrofotometer UV-Vis.

\subsection{Analisis Data}

Data yang diperoleh dianalisis pengaruh dan keterkaitan antar variabel menggunakan Annova dua arah dengan tingkat kebermaknaan $(\alpha) 5 \%$. Software yang digunakan untuk menganalisis data Microsoft Excel 2013.

\section{Hasil dan Pembahasan}

\subsection{Kadar Air}

Tepung yang diujikan meliputi hasil perendaman selama 1, 2, 3, 4, dan 5 jam dengan pH 9 serta pengecekan kadar air tiap 10 menit selama 60 menit. Berdasarkan hasil analisa kadar air tepung labu kuning yang telah dilakukan, diperoleh niai yang variatif. Kadar air tepung untuk waktu perendaman $1,2,3,4$, serta 5 jam berturut-turut adalah $11 \% ; 12 \% ; 27,50 \%$; 10\%; dan 18\% (Gambar 1). Kadar air paling baik diperoleh pada hasil perendaman selama 4 jam, nilai $10 \%$. Jika dibandingkan dengan kadar air tepung terigu hasil analisa yakni 11,40\% dan kadar air menurut SNI 3751:2009 [12] maksimum 14,5\%, maka kadar air tepung labu kuning yang dihasikan relatif lebih rendah. Dari hasil penelitian yang diperoleh sampel yang mendekati kadar air tepung terigu adalah waktu perendaman 1 jam, sehingga kondisi ini dipilih sebagai kondisi optimal sebesar 11\%. Hasil analisis statistik menunjukkan ada beda nyata pada setiap variabel waktu perendaman yang dipilih terhadap kadar air yang diperoleh ( $p$-value 0,42$)$.

Kadar air berpengaruh pada waktu penyimpanan. Semakin kecil nilai kadar air, maka yang lebih lama waktu penyimpanannya, serta kualitas tepung yang lebih baik. Perbedaan kadar air yang demikian disebabkan oleh penyerapan air di udara bebas oleh tepung labu kuning lebih cepat dibanding tepung jenis lainnya. Selain itu, pengaruh sebaran ukuran luas permukaan saat pemanasan juga berpengaruh pada jumlah air yang teruapkan, dan menghasilkan variasi kadar air yang beragam. Hal ini yang mempengaruhi peningkatan kadar air pada perendaman 3 jam [15].

Karakteristik tepung yang higroskopis atau mudah menyerap air inilah yang membuat tepung labu kuning harus benar-benar disimpan dengan wadah tertutup dan pada temperatur ruang yang kering untuk mencegah tumbuhnya jamur pada tepung. Karakteristik higroskopik pada tepung labu kuning dikarenakan tingginya kandungan gula sederhana dalam tepung [15].

\subsection{Daya Kembang (Swelling Power)}

Berdasarkan hasil penelitian yang dilakukan, swelling power untuk variasi waktu perendaman selama 1, 2, 3, 4, dan 5 jam menunjukkan adanya perbedaan yang cukup signifikan. Swelling power yang diperoleh $7,2(\mathrm{~g} / \mathrm{g}) ; 9,1(\mathrm{~g} / \mathrm{g}) ; 9,2(\mathrm{~g} / \mathrm{g}) ; 9,1(\mathrm{~g} / \mathrm{g}) ;$ dan $9,6(\mathrm{~g} / \mathrm{g})$. Untuk tepung tanpa perendaman sebesar 12,4 (g/g) serta tepung terigu sebesar 8,7 (g/g). Dari hasil analisa tersebut, dapat diketahui bahwa tepung labu kuning dengan nilai swelling power optimal pada perendaman 1 jam sebesar 7,2 g/g karena lebih mendekati swelling power tepung terigu. Hasil analisa statistik 
menunjukkan tidak ada perbedaan nyata antara variabel waktu perendaman dengan hasil daya kembang (p-value 0,057).

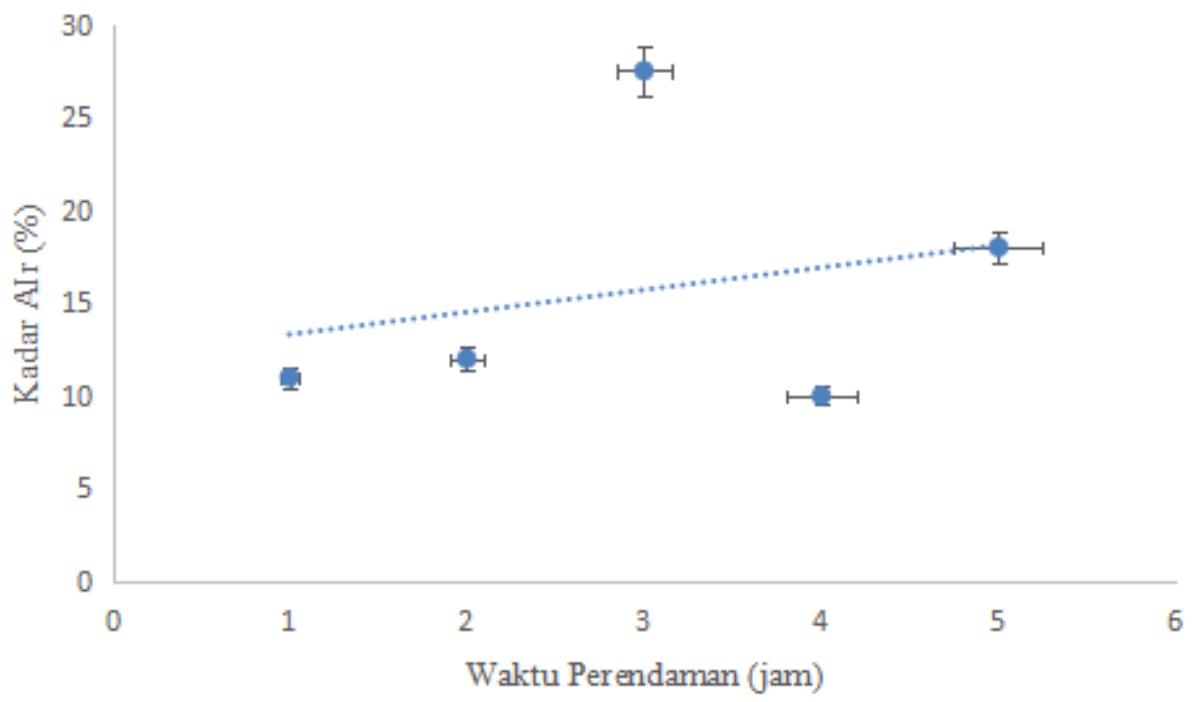

Gambar 1. Pengaruh Waktu Perendaman terhadap Kadar Air Tepung Modifikasi Labu Kuning

Semakin tinggi nilai swelling power suatu tepung, maka akan semakin meningkat elastisitas dari tepung tersebut. Hal ini disebabkan oleh adanya rantai amilopektin yang lebih panjang, dan berbanding terbalik dengan kandungan amilosa yang semakin sedikit seiring dengan bertambahnya nilai swelling power. Budiarti [9] menyatakan bahwa swelling power pada suasana asam akan cenderung lebih kecil karena amilosa akan lebih mudah terpecah, sedangkan pada suasana basa amilosa cenderung stabil dan tidak mudah terpecah. Pengelompokan swelling power menurut Indrianti et al. [16] terbagi atas tiga jenis yakni swelling tinggi, swelling sedang, dan swelling terbatas. Swelling tinggi bernilai $30(\mathrm{~g} / \mathrm{g})$ atau lebih, swelling sedang bernilai $16-20(\mathrm{~g} / \mathrm{g})$ dan swelling terbatas bernilai 9-11,03 (g/g) dalam pemanasan pada suhu $95^{\circ} \mathrm{C}$. Oleh karena itu, tepung labu kuning termasuk dalam kelompok swelling terbatas sehingga dalam penggunaannya lebih sering dijadikan sebagai subtituen tepung terigu sebagai campuran bersama tepung lainnya karena memiliki karakteristik swelling power yang mirip.

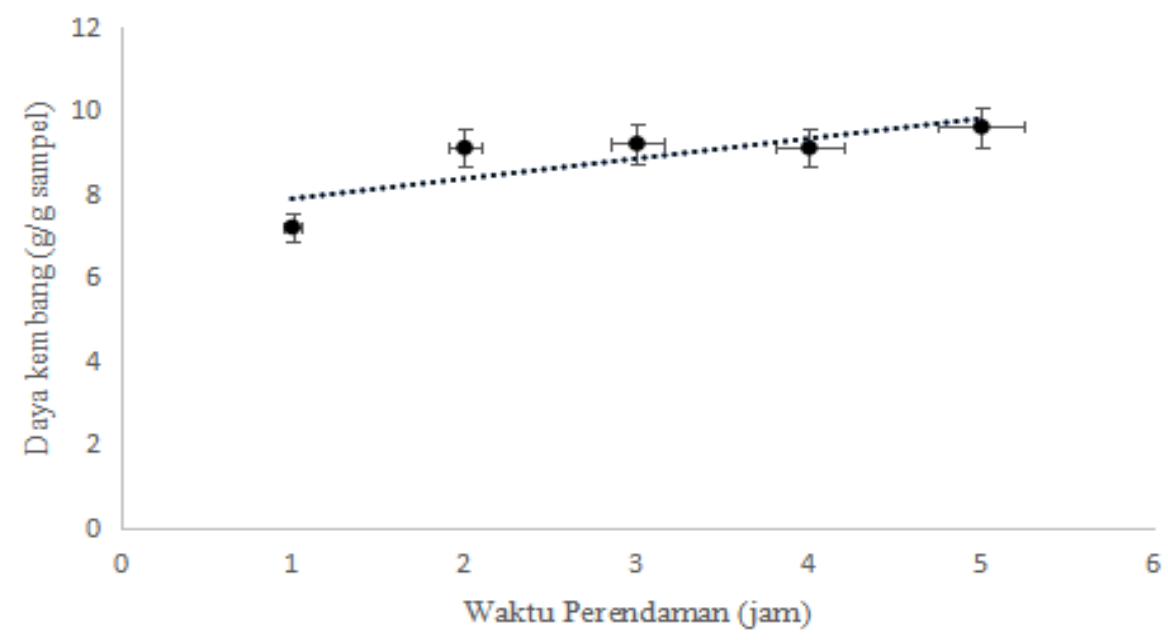

Gambar 2. Pengaruh Waktu Perendaman terhadap Daya Kembang Tepung Modifikasi Labu Kuning

Penelitian sebelumnya tepung termodifikasi dengan pengering oven menghasilkan daya kembang pada kisaran 1,24-2,15 g/g sampel. Hasil daya kembang tepung termodifikasi HRW dengan pengering gelombang mikro lebih tinggi dibandingkan dengan oven. 


\subsection{Kandungan Beta Karoten}

Dari Gambar 3 menunjukkan bahwa kadar beta karoten pada tepung labu kuning mengalami penurunan. Hasil yang diperoleh pada variasi waktu 1, 2, 3, 4, dan 5 jam berturut-turut adalah

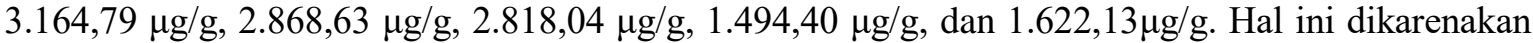
efek pemanasan pada proses pengeringan. Menurut Budiarti dan Sulistiawati, bahwa suhu optimal untuk beta karoten dapat terjaga yaitu pada suhu $45-60{ }^{\circ} \mathrm{C}$ [9]. Pada alat gelombang mikro tidak ada indikator suhu, namun pemanasan atau pengeringan lebih cepat dibandingkan pengering oven maupun matahari. Faktor lain yang mempengaruhi adalah waktu perendaman, semakin lama labu direndam, maka akan banyak air yang masuk, membuat karoten larut dalam HRW. Hal ini sesuai dengan penelitian Budiarti dan Sulistiawati [9] semakin lama waktu perendaman kandungan beta karoten semakin turun. Kadar beta karoten yang diperoleh lebih tinggi dibandingkan dengan penelitian terdahulu modifikasi labu kuning dengan HRW tanpa gelombang mikro yaitu antara 340$160 \mu \mathrm{g} / \mathrm{g}$ [8]. Hasil kadar beta karoten optimal pada waktu perendaman 1 jam sebesar 3.164,79 $\mu \mathrm{g} / \mathrm{g}$. Hasil statistik untuk pengaruh waktu perendaman terhadap nilai beta karoten menunjukkan adanya perbedaan yang signifikan dengan nilai $p$-value 0,42 .

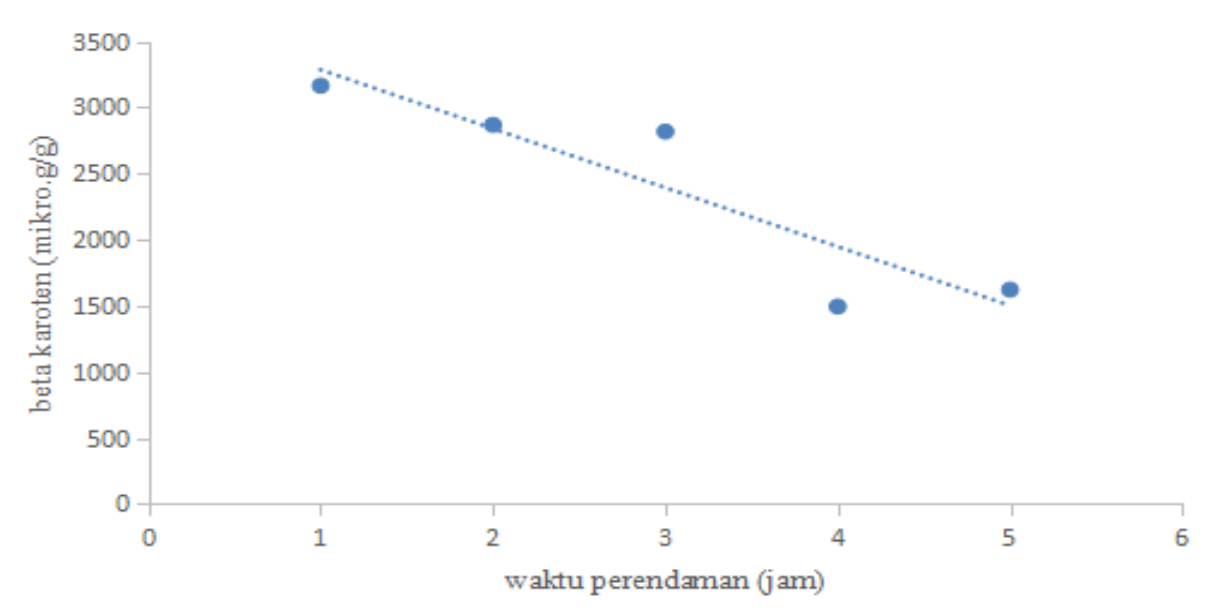

Gambar 3. Pengaruh Waktu Perendaman terhadap Kadar Beta Karoten Tepung Modifikasi Labu Kuning

\section{Kesimpulan}

Berdasarkan penelitian yang telah dilakukan dapat disimpulkan bahwa hasil optimal diperoleh pada waktu perendaman 1 jam. Hasil kadar air, daya kembang dan beta karoten berturut-turut sebesar $11 \%, 7,2 \%$, dan 3.164,79 $\mu \mathrm{g} / \mathrm{g}$. Hasil daya kembang dan beta karoten pada tepung termodifikasi HRW menggunakan pengering gelombang mikro lebih tinggi dibandingkan menggunakan oven. Metode ini dapat dipertimbangkan untuk di scale up ke skala industri atau UMKM.

\section{Daftar Pustaka}

[1] Mirhosseini, H. Rashid, NFA. Amid, BT. Cheong, KW. Kazemi, M.Zulkurnain, M,"Effect of partial replacement of corn flour with durian seed flour and pumpkin flour on cooking yield, texture properties, and sensory attributes of gluten free pasta", LWT-Food Science and Technology Vol. 63. 184-190, 2015

[2] Triyani, Anjar, Dwi Ishartani, and Dimas Rahardian."Kajian Karakteristik Fisikokimia Tepung Labu Kuning (Cucurbita Moschata) Termodifikasi Dengan Variasi Lama Perendaman Dan Konsentrasi Asam Asetat." Teknosains Pangan 2 (2): 17-18, Februari 2013.

[3] Ahmed,J, Al-Foudari, M, Al-Salman,F, Almusallam,A,S, "Effect of particle size, and temperature on rheogical, thermal, and structuralpropertiesof pumpkin flour dispersion", Journal of Food Engineering, Vol.124, pp. 43-53, 2014. 
[4] Prabasini Hehmaning. Kajian Sifat Kimia Dan Fisik Tepung Labu Kuning (Cucurbit Moschata) dengan Perlakuan Blanching Dan Perendaman Dalam Natrium Metabisulfit $\left(\mathrm{Na}_{2} \mathrm{~S}_{2} \mathrm{O}_{5}\right)$.Jurnal Teknosains Pangan Vol 2.No.2, hal.94-99, Februari 2013

[5] Juanda, C,E, Meilliza, V, "Studi Preferensi Konsumen terhadap Roti Tawar Labu Kuning (Curcubita moschatta)" Jurusan Teknologi Hasil Pertanian, Fakultas Pertanian, Universitas Syiah Kuala Darussalam, Banda Aceh, 2012

[6] Zulaidah, A, "Peningkatan Nilai Guna Pati Alami Melalui Proses Modifikasi Pati", Jurusan Teknik Kimia FT Universitas Pandanaran. 2012.

[7] Zhu, Fan, "Review Composition, Structure, Physicochemical Properties, and Modifications of Cassava Starch." Carbohydrate Polymers 122. Elsevier Ltd. 456-80, 2015.

[8] Zhao, Ming, Ming-dong Liu, Ying-yan Pu, Dan Wang, Yu Xie, Gai-ci Xue, Yong Jiang, Qian-qian Yang, Xue-jun Sun, and Li Cao, "Hydrogen-Rich Water Improves Neurological Functional Recovery in Experimental Autoimmune Encephalomyelitis Mice." Journal of Neuroimmunology. Elsevier B.V, 2016.

[9] Budiarti, G,I, Sulistiawati,E, "Modifikasi Tepung Labu Kuning Menggunakan Hydrogen Rich Water Sebagai Pengganti Gandum”, Prosiding SENATEK Purwokerto, 2017.

[10] Singh, V., Tiwari, A., Kumari, P., and Tiwari, S, "Microwave-Promoted Hydrolysis of Plant Seed Gums on Alumina Support”, Carbohydrate Research, 341, pp. 2270-2274, 2006.

[11] Budiarti, GI., Sulistiawati, E, “Aplikasi hydrogen rich water pada modifikasi tepung kentang dengan pengering gelombang mikro sebagai alternatif subtitusi gandu”, Elkawnie : Journal of Islamic Science and Technology.Vol. 5 (2): 128-138, 2019.

[12] -, "Standar Nasional Indonesia Tepung Terigu SNI 3751:2009”, 2009.

[13] Gumolung, D, “Analisis Beta Karoten Dari Ekstrak Jonjot Buah Labu Kuning (Curcubita moschata)", Fullerene Journal of Chemistry. Vol .2 (2): 69-71, 2017.

[14] Kusumayanti, H., Handayani, N. A., Santosa, H, "Swelling Power And Water Solubility Of Cassava And Sweet Potatoes Flour. Procedia enviromental sciences, 23, 164-167, 2015.

[15] Hartati, Sri, "Formulasi Tepung Terigu Dan Labu Kuning (Cucurbita Moschata Durch) Terhadap Sifat Fisik, Kimia Dan Organoleptik Kue Bakpao”, Jurusan Ilmu Dan Teknologi Pangan Fakultas Pertanian Peternakan Universitas Muhammadiyah. Malang, 2015.

[16] Indrianti,N, Afifah, N, Sholichah, E, “ Pembuatan Tepung Komposit dari Pati Ganyong/ Garut dan Tepung Labu Kuning sebagai Bahan Baku Flat Noodle”, Bioporal Industri, Vol.1, No. 1, 2019. 